\section{書 評}

井原泰雄・梅崎昌裕 - 米田穣 編『人間の本質にせ まる科学 自然人類学の挑戦』東京大学出版会 2021年 3 月刊 2,500 円 (税別) (280ページ)

人間の本質を、多様な文化や社会活動の視点から理 解しようとするのが文化人類学とすれば、環境への適 応や進化という生物学的な視点から理解しょうとする のが自然人類学であるといえよう。本書のまえがきで、 長年チンパンジーやヒトの行動生態を研究してきた長 谷川寿一氏は、自然人類学が持つ命題は「我々はどこ から来たのか、我々は何者か、我々はどこ一行くのか」 を明らかにすることであると述べている。

霊長類学も、サルの行動や社会の研究を通じて人間 社会の起源を明らかにするという目標を揭げて始まっ た（中村，2015）。また、私たちヒトも霊長類の 1 種で あることから、ヒト以外の霊長類を対象とした研究で あっても、「霊長類としての人間の本質」にせまる科学 たりえるはずである。

本書は東京大学の教養学部前期課程 (進学振分け前 の $1 \sim 2$ 年生) 向けに開講された「自然人類学」のオムニ バス講義をベースとしてまとめられている。ゲノム、化 石形態、生理、腸内細菌、といった多岐にわたるトピ ックの最新の研究動向を踏まえ、自然人類学を網羅的 に学ぶことのできる教科書として作られている。本書 は4 部構成で、15章と7つのコラムを掲載している。各 章とコラムの執筆者には、各分野における第一線の研 究者たちがずらりと名を連衫ており、基礎から先端ま でを網羅する案内者としてこの上ない陣容である。

第 I 部「人類進化の歩み」ではヒトの進化史を概観す る。まず、第 1 章はヒトが属する霊長類の行動や社会 の特徵についてのレビューである。ヒトの形質を特別 視するべきではなく、ヒト以外の霊長類種との比較に よって相対化してとらえるべきであると勧告する。第 2 章からは直立二足歩行を始めた猿人、ホモ属、旧人、 新人という人類の進化史の流机を、化石形態学や考古 学の知見を中心に追いつつ概観する。これほど多様な 人類が生まれては絶滅を繰り返した中、なぜホモ・サ ピエンスだけが現代まで生き残り、世界中に拡散した のだろうか。その真相は依然未解明であるようだ。

第 II 部「ヒトのゲノム科学」では、遺伝学の観点から 人類進化に関する最新の知見が紹介される。トピック は人類の遺伝的多様性、全ゲノム解析、形質多様性と 自然選択、古代ゲノムといった内容である。解析技術 の急速な進展によって、DNAから現生および過去の人 類の生態に関する膨大な情報を引き出すことができる ようになってきたことがわかる。また、ネアンデルタ ール人やデニソワ人などの古代人類のゲノムが、ホモ・
サピエンスとの交雑の結果、現生人類にも引き継がれ ていると明らかになったことは近年の重要なトピック であろう。絶滅したはずの人類が私たちの中に生きて いるという驚くべきストーリーからは、実は恐竜は鳥 として生きているのだと知らされたときのような感動 を覚える。

第III部「生きているヒト」の内容は多様である。人類 をその他の霊長類と分ける最大の特徵である直立二足 歩行の進化、色覚の多様性と進化、環境への生理的適 応能、環境適応に関わる腸内細菌についての解説がな される。アフリカ熱帯林で進化した霊長類に出自を持 つ人類が、なぜ乾燥地や温帯、寒帯にまで適応し、果 ては高山や宇宙空間にまで進出できたのだろうか。第 I 部で解説された人類の世界的拡散を可能としたのは 様々な環境に適応できる能力にあり、9１2章では過 酷な環境を生き延びた人類の力の源泉を知ることがで きる。

最後に第IV部「文化と人間」では、人類の文化現象に ついて自然人類学の視点から掘り下げる。人類を特徵 づける最大の能力であり、多様な文化の基盤となる言 語の進化、放射性同位体分析が可能とする過去の人類 の生業や生態の解明、そして霊長類学者も留意す心゙き 「人種」概念と差別の歴史について知ることができる。 特に人種は現在も続く差別の歴史と密接し、「我々はど こへ行くのか」に結びつくテーマである。人類学が植 民地主義の元で生まれたことを自認し、その反省のも と人類の多様性に関する知見を社会に還元する意義を 説いていることはとても印象的であった。ヒト以外の 霊長類の形態や行動、生態、社会の中にも当然様々な レベルでの多様性が存在する。この「いろいろある」と いうことをどのようにすれば自身の研究の中で位置づ け、人類学と同様に社会へ発信することができるだろ うか。

全体を通読すると、本書で紹介されている手法の多 くはヒト以外の霊長類を対象としても適用されている ものが多いため、研究手法に関しては霊長類学会員に

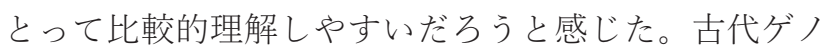
ムや放射性同位体、腸内細菌に関する研究手法につい て、自身が研究する霊長類種に当てはめればどのよう な結果が得られるだろうかと想像しながら読めばより 楽しいし、新たな道筋が見えることもあるかもしれな い。

また、「人間の本質にせまる研究」には文理は関係な く、幅広い知識が必要であるとも感じた。過去の人類 の生態を明らかにする上では歴史学の知識が助けにな り、人類の直立二足歩行のメカニズムを解析する上で は物理学の知識が必要である。気象、地理、芸術、植 物の系統分類、あらゆる知識は「人間の本質」の理解に つながりうる。大学受験のために「文系」を選択した 
（している）学生も、「理系」を選択した（している）学 生も、自身の興味や知識を生かすことのできる人類学 の研究テーマがきっとあることだろう。大切なのは人 間という生き物に対する好奇心であることを本書から は感じた。

そうした観点で見ると、巻末の自然人類学を学べる 大学院リストは進路を決める際にとても役立つ情報で ある。評者が高校生の頃にも、人類学や動物学の大学 院を紹介するムックを読み、どの大学へ行けば自身の 興味にあった研究ができそうかということを考えた経 験がある。研究者を志望する高校生・大学生に向けた 教科書の付録だからこそ、こうしたリストは重要であ ると思う。ただし、リストとしては『日本のサル学の あした』(中川ら編, 2012) に掲載されていた写真つき の研究室紹介の方が目につきやすく、研究室の雾囲気 も想像しやすかった。できれば本書のリストも研究室 名を列挙するだけでなく、もっと見やすいレイアウト で揭載した方がよかったのではないだろうか。

2022 年 9 月には日本霊長類学会と日本人類学会の合 同大会が開催される。「人間の本質」を探究する学問の 徒として、両学会の会員の間で実りある交流を行える はずである。来年の合同大会を楽しむためにも、特に 本書を霊長類学会の若手会員に読んでもらいたい。

\section{引用文献}

中川尚史、友永雅己、山極寿一 編 2012 : 「日本のサル学のあし た 霊長類研究という「人間学」の可能性」京都通信社

中村美知夫 $2015 「 サ ル$ 学の系譜 人とチンパンジーの 50 年」中 公叢書

(京都大学宇宙総合学研究ユニット 田島知之

tajima.tomoyuki.4s@kyoto-u.ac.jp) 